Cezary Zalewski

Uniwersytet Jagielloński

\title{
W świetle powyższej (pobieżnej) analizy: Studium fotografii w Komentarzach do fotografii Witolda Wirpszy
}

\section{Ustalenia wstępne}

Fenomen Komentarzy do fotografii Witolda Wirpszy wynika w dużej mierze z kontrastowego (i efektownego) zestawienia między partiami deskrypcyjnymi oraz - powstałymi na ich kanwie - kreacjami wyobrażeniowymi (Kwiatkowski 1963: 9; Grądziel-Wójcik 2001: 52). Jednakże ta jukstapozycja nie obejmuje struktury wszystkich utworów: biorąc pod uwagę te z nich, które mają bezpośredni związek wyłącznie z jedną fotografią, trzeba zauważyć, że niemal połowa nie została wyposażona w, jak ujął to Jerzy Kwiatkowski, „elementy swoistej fantastyki”. Poetyka całego cyklu zakłada zatem wyraźnie różnicę między obecnością (w siedmiu wierszach) i brakiem (w sześciu wierszach) tej jukstapozycji. Faktu tego nie można zignorować, wręcz przeciwnie - należy uznać go za rodzaj opozycji znaczącej, która generuje dwie grupy odmiennie zbudowanych utworów. Szukając mechanizmów odpowiedzialnych za tę zmianę, wskazać trzeba na - mówiąc ogólnie - zupełnie inny rodzaj interakcji między oglądającym i mówiącym podmiotem a fotograficznym obrazem.

Dokładniejszego ujęcia tej kwestii można dokonać, posługując się znaną parą pojęć, którą w Świetle obrazu wprowadził Roland Barthes (1996). Jeśli zatem przyjąć, że percepcja fotografii wywołuje silny wstrząs afektywny, którego efektem jest ów konstrukt fantazmatyczny, wówczas ten tryb interakcji można 
by określić mianem punctum. Siedem utworów cyklu Wirpszy spełnia ten warunek, natomiast sześć pozostałych realizuje taki sposób obcowania z obrazem, który Barthes określa jako studium (Barthes 1996: 46-47) Jest to rodzaj analizy: zakłada ona dystans oraz pewną dociekliwość, której celem jest dotarcie do znaczeń fotografii dzięki wykorzystaniu popularnej wiedzy i kompetencji kulturowych oglądającego. Barthes jest zresztą przekonany, że ostateczny efekt tej procedury jest następujący:

Rozpoznać studium to siłą rzeczy spotkać się z intencjami fotografa, wejść z nimi w porządek harmonii, przyjąć je lub odrzucić. Ale zawsze się je rozumie, dyskutuje w sobie, gdyż kultura (do której należy studium) jest umową zawartą między twórcami i konsumentami. Studium to rodzaj wychowania (wiedza i grzeczność), które pozwala mi odnaleźć Operatora, żyć celami, które wywołują i podtrzymują jego praktyki, ale żyć tym w pewnym sensie na odwrót, według widzimisię Spectatora (Barthes 1996: 48-49).

Rozpoznanie zamiaru i jego realizacji nie dostarcza jednak ekscytujących doświadczeń. Jeśli bowiem percepcja obrazu poprzestaje wyłącznie na etapie studium, wówczas okazuje się, że:

powstaje pewien bardzo rozpowszechniony rodzaj zdjęcia [...], który można by nazwać fotografia jednolita. [...] Fotografia jest jednolita, jeśli wyolbrzymia „realność”, nie podwajając jej, nie naruszając (przesada zapewnia tu spójność): żadnego rozdwojenia, wszystko jest bezpośrednie, niezachwiane (Barthes 1996: 71).

Dociekania Barthesa pozostają tu zgodne z bardziej rozbudowanymi propozycjami autorów Reading Images (Kress, Leeuwen 2006). Przekonania dotyczące realności fotograficznej reprezentacji określają oni mianem modalności, podkreślając, że niekiedy bywa ona bardzo niska. Wszystko zależy bowiem od tego, w jaki sposób obraz został zakodowany, a reguły, które tu funkcjonują, mają charakter społeczny lub instytucjonalny. Zasady te dotyczą takich jakości (tzw. markerów modalności) jak: nasycenie kolorystyczne, obecność tła, dokładność reprezentacji, głębia, oświetlenie, jasność (Kress, Leeuwen 2006: 160-162). W pierwszym z nich - omawianym najszerzej - może dochodzić do najróżniejszych efektów: to samo zdjęcie, operujące w określony sposób kolorami, może uchodzić za mało prawdopodobne, realistyczne czy wręcz hiperrealistyczne. Ta ostatnia wartość najwyższej modalności przysługuje fotografiom czarno 
-białym (a takie przecież znajdują się w tomie Wirpszy) wtedy, gdy zostały wytworzone przy użyciu wyrafinowanych procedur. Autorzy określają je mianem abstrakcyjnych orientacji kodujących (abstract coding orientations), które:

są używane przez socjokulturowe elity - w „wysokiej” sztuce, w akademickich i naukowych kontekstach, i tak dalej. W takich kontekstach modalność jest wyższa tym bardziej, im bardziej obraz redukuje to, co indywidualne do tego, co ogólne; to, co konkretne do jego istotowych właściwości. Zdolność produkowania i/lub czytania tekstów opartych na tej kodującej orientacji jest znakiem przynależności społecznej, bycia „wykształconą osobą” czy „poważnym artystą” (Kress, Leeuwen 2006: 165).

Inspiracje płynące z pobieżnie przywołanych tu teorii można ująć za pomocą następujących ustaleń. Grupa sześciu utworów Wirpszy realizuje poetykę deskryptywną, ponieważ oparta jest na „studiowaniu” elementów fotografii, niekiedy nawet intencji, które doprowadzily do ich powstania. Obrazy te - prima facie - prezentują się jako bardzo realistyczne, jako „sama” rzeczywistość, do której bezpośredni dostęp ma oglądający (i piszący). Czarno-biała technika, ustawienie tła, perspektywiczna głębia, dbałość o detale, dobre oświetlenie (poza jednym zdjęciem wykonanym w nocy), operowanie światłocieniem - wszystko to kształtuje wysoką wiarygodność, która okazuje się niezbędna właśnie ze względu na uniwersalizujący charakter zdjęć'.

\section{Warunki studium/zasady przekładu}

Rozpoznanie wzajemnej interakcji (obrazu i słowa) wymaga rekonstrukcji jej założeń czy warunków wstępnych. Otwarcie każdej strony tomu dostarcza, jak wiadomo (Grądziel-Wójcik 2001: 54; Pawelec 2013: 141), kontaktu aż z trzema zintegrowanymi rodzajami tekstów kultury: fotografii, wyjaśniającego ją podpisu i wiersza. Konstrukcja taka nie jest oczywista: badanie inspiracji, jaką literatura (a zwłaszcza poezja) może zawdzięczać fotografii, częściej wskazuje na takie realizacje, które albo ukrywają zupełnie ów źródłowy obraz, albo zaledwie

1 Jak wiadomo, był to podstawowy cel samej wystawy The family of Man. W katalogu ekspozycji można było przeczytać m.in.: „Wystawa [...] pokazuje, że sztuka fotografii jest dynamicznym procesem nadawania formy ideom i tłumaczenia człowieka człowiekowi. Została pomyślana jako zwierciadło uniwersalnych czynników i emocji w codzienności życia - jako zwierciadło istotnej jedności ludzkości na całym świecie” (Steichen 1955: 5). 
odsyłają do niego w sposób mniej lub bardziej dokładny². Decyzja Wirpszy zaskakuje tym bardziej, że fotografie - jako obiekt wzbudzającej duże zainteresowanie wystawy - funkcjonowały już w obiegu publicznym (por. Jankowicz 2017; Leśniak 2013). Nie ulega zatem wątpliwości, że istniał tu wyraźny zamiar podwójnej konfrontacji, jakiej miał podlegać odbiorca: i ze zdjęciami, i z odnoszącymi się do niego tekstami³. Konsekwencje tego zabiegu mają fundamentalne znaczenie. To one wskazują bowiem, w jaki sposób Wirpsza dokonał przekładu intersemiotycznego między znakiem wizualnym a słownym. W nieco abstrakcyjny sposób można tę translatorską strategię określić przy pomocy trzech reguł.

\subsection{Zasada redukcji i indeksacji poetyckiego opisu}

Porównanie fotografii i utworu lirycznego natychmiast prowadzi do wniosku, że ten drugi przedstawia zaledwie fragmenty tego, co zostało pokazane na obrazie. Dlatego partie deskrypcyjne są tu zarówno nieliczne, jak i pozbawione rozbudo-

2 Znamienne są pod tym względem ustalenia Jane Rabb: „Od lat sześćdziesiątych pisarze, szczególnie zaś poeci - niezależnie od tego, czy sami używali aparatu czy nie - bardzo często inspirowali się fotografią. Niektórzy zostali zainspirowani fotografiami z książek dokumentalnych, [...] popularnych pism [...] i gazet [...]. Inni zwracali się ku konkretnym obrazom wykonanym przez znanych fotografików [...]. Bardzo wielu [wyróż. - C.Z.] odnajdowało w prywatnych fotografiach źródło osobistej liryki [...]. Takie prywatne zdjęcia, które z łatwością budziły wspomnienia, wymagały specyficznej precyzji, żeby przywołać czytelnikom zarówno je, jak i dołączone uczucie [...]" (Rabb 1995: li-lii). Dodać jeszcze należy, że to właśnie częste wykorzystywanie prywatnych zdjęć było (najprawdopodobniej) powodem unikania ich publikacji. Stwarzało to dla czytelnika sytuację dyskomfortową, którą znakomicie określił Marian Stala, komentując Fotografię Z. Herberta: „gotów byłbym jednak przysiąc, iż chodzi o konkretne, realnie istniejące i dobrze autorowi znane zdjęcie. Gotów byłbym także przysiąc, iż jest to fotografia młodego Herberta. Moje przeświadczenia są mocne, nie mogę ich jednak uzasadnić czytając napisane przez poetę zdania" (Stala 2000: 400).

3 Dzięki drugiej edycji Komentarzy (por. Wirpsza 2017) dysponujemy już faksymile przedmowy, której nie udało się poecie - prawdopodobnie ze względów cenzuralnych opublikować w 1962 roku. Wirpsza explicite stwierdza w niej swój krytyczny zamiar, zarazem jednak wyjaśnia, że umieścił w tomie fotografie, aby umożliwić im „obronę” przed swoim atakiem. Fragment ten (bez widocznych zmian i skreśleń) brzmi następująco: „Utwór więc, który napisałem, jest utworem polemicznym - i tym usprawiedliwiam moją stronniczość i niesprawiedliwość. Całość ukaże się niebawem w wydaniu książkowym zaopatrzonym w odpowiednie zdjęcia - myślę, że w ten sposób, dawszy głos arcyświątobliwemu przeciwnikowi, grzechy moje częściowo chociaż odkupię" (Wirpsza 2017: 5). 
wanych ujęć jakościowych. Wraz z minimalizacją występuje także znaczne ich rozproszenie: rzadko tworzą one zwarty i wyodrębniony blok, częściej zostają bowiem umieszczone w rozmaitych miejscach lirycznego monologu. Trudno jest na ich podstawie przeprowadzić jakąkolwiek rekonstrukcję zawartości zdjęcia, a już na pewno nie sprawiają, że obraz ten zostaje zaprezentowany w sposób pozwalający na pełną i natychmiastową wizualizację ${ }^{4}$.

Zadanie elementów deskrypcyjnych ogranicza się zatem do funkcji indeksacyjnej, wskazującej. Tworzą one odniesienie monologu lirycznego do fotografii, której percepcja powinna poprzedzać lekturę. Mówiąc dokładniej, zminimalizowane opisy nie są autonomiczne, ponieważ to właśnie one podtrzymują relację między dwoma typami reprezentacji, zmuszając do oglądania i czytania. Dzięki temu w procesie odbioru powstaje swoisty dyptyk: jedna całość, która wszakże składa się z dwóch, ustawionych naprzeciwko siebie części.

Mechanizm ten jest zasadniczy, ale nieoczywisty. Wydaje się bowiem, że między oboma członami dyptyku więcej jest różnic niż podobieństw. Wrażenie takie jest dodatkowo wzmacniane podpisami, które umieszczone zostały pod każdą fotografią. Ich forma jest lakoniczna i pobieżna, ale w ten sposób Wirpsza pokazuje, że w obrębie dyskursu pozaliterackiego można zbudować adekwatny (chociaż skrajnie uproszczony) przekład obrazu na słowo. Implicite oznacza to, że w przypadku poezji relacja ta będzie przebiegać inaczej: w sposób zaburzony, napięty, a przede wszystkim - bez ambicji całościowych, bez zamiaru dokładnego odtworzenia tego, co znajduje się na zdjęciu. W zamian za to - jak należy przypuszczać - wiersz przyniesie znacznie więcej potencjału poznawczego, który w krótkich - tautologicznych, by tak rzec - „objaśnieniach” jest niemal nieobecny.

W tym kontekście warto zwrócić uwagę, że graficzny układ dyptyków zawiera wyraźną sugestię kompozycyjną. Obraz - najczęściej także jego opis jest na lewej stronie, a liryczny komentarz - na prawej i obie te części zajmują bezpośrednio połączone ze sobą partie książki, nigdy się nie rozdzielając. Ta horyzontalna kolejność, która wprowadza linearne pierwszeństwo fotografii względem wiersza, naprowadza na (często wykorzystywane w analizach multimodalnych) następstwo typu: datum - novum. W Reading Images znaleźć można następującą definicję:

Elementy umieszczone po lewej są przedstawiane jako to, co Dane (Given), elementy umieszczone po prawej - jako Nowe (New). To, że coś jest Dane, oznacza, że jest przedstawiane jako coś, o czym ogląda-

4 Taka jest bowiem zasadnicza funkcja opisu w utworach poetyckich (zob. Bernhart 2007). 
jący już wie, jako coś znanego i stanowiącego zaakceptowany punkt wyjścia przekazu. To, że coś jest Nowe, oznacza, że jest przedstawiane jako coś, co nie zostało jeszcze rozpoznane, lub być może jako coś, co nie zdobyło jeszcze akceptacji odbiorcy, zatem jako coś, na co musi on zwrócić szczególną uwagę. Mówiąc ogólnie, znaczenie Nowego jest więc „problematyczne”, „sporne”, „dyskusyjne”; podczas gdy Dane jest przedstawione jako zdroworozsądkowe, oczywiste (Kress, Leeuwen 2006: 181).

Dla Wirpszy fotografie $\mathrm{z}$ wystawy zawierają przekaz nieskomplikowany i czytelny (ewentualne wątpliwości rozstrzyga podpis), dlatego odbiorca z nimi właśnie powinien zapoznać się w pierwszej kolejności. Komentarz pojawia się później, ponieważ zawiera korektę, do której prowadzi wnikliwy (i krytyczny) namysł nad zawartością zdjęcia. Zindeksowane opisy nie pozwalają odbiorcy zapomnieć, że zadaniem monologu lirycznego jest reinterpretacja wizualnej oczywistości.

\subsection{Zasada analogii formalnej}

The Family of Man składała się, jak wiadomo, z 503 fotografii. Intrygująca pozostaje zatem kwestia dokonanego przez poetę wyboru, który objął zaledwie trzynaście zdjęć (czternaste zostało umieszczone na okładce tomu). Można np. zwrócić uwagę na fakt, iż w przypadku omawianych tu dyptyków pojawiają się fotografie, które operują wyłącznie perspektywą wertykalną. Takich związków o charakterze technicznym będzie można dostrzec nieco więcej, jednak by tego dokonać, konieczne jest dalsze zawężenie zakresu analiz. Z sześciu par zostaną cztery, które wprowadzają ludzkie postacie (dwie pozostałe dotyczą tylko natury).

W Reading Images znajdują się inspirujące rozważania dotyczące tzw. znaczeń interakcyjnych, czyli tego, w jaki sposób fotografia „ustawia”, projektuje pozycję swojego odbiorcy. Proces ten dokonuje się na trzech płaszczyznach: kontaktu, społecznego dystansu i punktu widzenia. Kategorie te mają wyłącznie antropomorficzny charakter: dotyczą tego, w jaki sposób sfotografowani ludzie są postrzegani przez tych, którzy ich oglądają. Każda z nich jest możliwa do rozpoznania, ponieważ przejawia się w konkretnym aspekcie formalnej struktury obrazu: w przebiegu trajektorii spojrzenia (kontakt), w sposobie kadrowania (społeczny dystans) i w ustawieniu perspektywy (punkt widzenia).

Pierwszy z tych parametrów jest skonstruowany binarnie: spojrzenie sfotografowanych albo zostaje skierowane bezpośrednio w stronę oglądającego, 
albo przechodzi gdzieś indziej. W pierwszym przypadku dochodzi do ustanowienia - choćby tylko wyimaginowanego - kontaktu.

Ta wizualna konfiguracja ma dwie powiązane funkcje. Po pierwsze tworzy wizualną formę bezpośredniego zwrotu. W sposób otwarty ustanawia odbiorców, zwracając się do nich za pomocą wizualnego "ty”. W drugiej kolejności konstytuuje „wyobrażone działanie”. Twórca używa tu obrazu, żeby wywrzeć jakiś wpływ na odbiorcę. Z tego właśnie powodu nazwaliśmy ten rodzaj obrazu „żądaniem” ('demand') [...]: spojrzenie sfotografowanych (oraz gest, jeśli jest obecny) domaga się czegoś od odbiorcy; domaga się, żeby odbiorca wszedł w jakiś rodzaj wyobrażonej relacji z nim lub nią (Kress, Leeuwen 2006: 118).

Sytuacja przeciwna wyklucza nawiązywanie kontaktu:

Rola odbiorcy polega na byciu niewidocznym obserwatorem. [...] Z tego powodu [...] nazwaliśmy ten rodzaj obrazu „propozycją" ('offer') - on „oferuje” ('offers') sfotografowane osoby oglądającemu jako jednostki informacji, obiekty kontemplacji, bezosobowo, jak gdyby były one okazami na wystawie (Kress, Leeuwen 2006: 119).

Drugi parametr dotyczy rozmiaru kadru prezentującego sylwetkę. Ujęcie bliskie koncentruje się niemal wyłącznie na twarzy (ewentualnie głowie), ujęcie pośrednie uwzględnia (maksymalnie) całą posturę, a odległe zakłada, że ludzka postać zajmuje nie więcej niż połowę obrazu, stając się elementem większej całości. Te różnice przekładają się na rozmaity rodzaj dystansu, który fotografia ustanawia między oglądającym i oglądanymi. W pierwszej sytuacji przyjmowana jest (bądź tylko wyobrażana) bliska, intymna relacja między obiema stronami; drugi typ ujęcia jest charakterystyczny dla tych interakcji, które są wymuszane przez wykonywanie zawodu lub pełnienie określonych ról społecznych, natomiast prezentowanie osób ze znacznej odległości sugeruje, że mają one pozostać obce, nieznajome (i w tym sensie bezosobowe) dla tych, którzy je oglądają (zob. Kress, Leeuwen 2006: 124-126).

Ostatni, trzeci wskaźnik ma związek z kątem widzenia, który zostaje narzucony odbiorcy. Zdjęcie nie jest „płaskie”, jednowymiarowe, funkcjonuje w nim bowiem perspektywa selekcjonująca i organizująca prezentację. Widz ogląda zatem fotografię uporządkowaną przy pomocy perspektywy poziomej (tzw. szerokiej) lub pionowej (tzw. wąskiej). W pierwszym przypadku kluczowa jest relacja między oglądającym a tym, co zostaje umieszczone na 
pierwszym planie. Jeśli to, co się tam znajduje, będzie pokazane tak, iż kąt widzenia można określić jako frontalny („z przodu”), wówczas implikowana jest postawa zaangażowana: to, co jest na zdjęciu, okazuje się częścią jednego, wspólnego świata. I odwrotnie: jeśli reprezentacja zostanie ustawiona ukośnie („pod kątem”), to sugestia zmierza w kierunku obojętności, dystansu i - ostatecznie - pewnego rodzaju wykluczenia (zob. Kress, Leeuwen 2006: 133-139). Perspektywa pionowa natomiast ma konotacje związane z grą siły i dominacji. Autorzy wyróżniają tu trzy podstawowe modele: jeśli pozycja oglądającego jest wyższa od tej, którą zajmuje sfotografowany, to ten pierwszy dysponuje symboliczną władzą nad tym drugim; w przypadku odwrotnym następuje analogiczna zamiana ról. Natomiast „jeśli wreszcie fotografia zostaje umieszczona na poziomie wzroku [oglądającego - C.Z.], wówczas punkt widzenia zakłada równość i żadna różnica w zakresie władzy nie zostaje przyjęta" (Kress, Leeuwen 2006: 140).

Biorąc pod uwagę powyższe ustalenia, można by pokusić się o pewne wnioski dotyczące wyboru, którego w swoich dyptykach dokonał poeta. Jego najbardziej wyrazistą decyzją było, jak wspomniałem, wykorzystanie fotografii wyposażonych tylko w perspektywę pionową, która - i to jest kluczowe - została tak ustawiona, że centrum kadru znajduje się dokładnie na poziomie wzroku odbiorcy. Jak się wydaje, Wirpsza zamierza w ten sposób wymknąć się binarnym dychotomiom: nie wybiera zdjęć z poziomym kątem widzenia, żeby nie rozstrzygać między zaangażowaniem i wykluczeniem, nie wybiera również perspektywy ani „od góry”, ani „od dołu”, żeby reguła dominacji nie została a priori narzucona. Poeta szuka zatem fotografii z perspektywą jak najbardziej neutralną, która sama o niczym jeszcze nie przesądza i wobec której - co jest chyba najważniejsze - patrzący może zachować pozycję partnerską, równorzędną, pozwalającą na swobodę.

$\mathrm{Z}$ tą ascetyczną strategią kontrastują decyzje podejmowane w zakresie pozostałych dwóch parametrów. Pod względem zarówno kontaktu, jak i dystansu poeta uwzględnił bowiem wszystkie możliwości. W skład dyptyków wchodzą zatem fotografie określone jako żądanie (Wirpsza 1962: 8) oraz propozycje (Wirpsza 1962: 10, 12, 28); są również tak wykadrowane, że posługują się ujęciem intymnym (Wirpsza 1962: 10), społecznym (Wirpsza 1962: 8, 12) oraz bezosobowym (Wirpsza 1962: 28). Trudno jest oprzeć się wrażeniu, że ta różnorodność (w obrębie zaledwie czterech obrazów) nie jest przypadkowa; wydaje się nawet, że poeta postanowił tak dobrać zdjęcia, aby uzyskać na ich podstawie określone zależności między parametrem pierwszym i drugim. Być może zresztą przeprowadzenie tych „eksperymentów” byłoby niemożliwe, gdyby parametr trzeci nie został zneutralizowany. 
Fotografie przedstawiające „rodzinę amerykańskich farmerów” (Wirpsza 1962: 8) oraz „prawnika w todze” (Wirpsza 1962: 12) wykorzystują kadr właściwy dla prezentacji ról społecznych. Wprawdzie na pierwszej z nich wszyscy patrzą w obiektyw, ale tych spojrzeń jest tak dużo, że żadne z nich nie narzuca się wyraźnie odbiorcy, nie domaga się więc niczego; natomiast na drugiej fotografii spojrzenie prawnika ucieka w bok, nie nawiązując żadnego kontaktu. Wirpsza wybiera więc fotografie, gdzie dystans społeczny bezpośrednio lub pośrednio eliminuje kwestię kontaktu wzrokowego, na który mógłby zostać wystawiony odbiorca.

Fotografia prezentująca „Murzyna pijącego wodę” (Wirpsza 1962: 10) posługuje się bliskim, intymnym sposobem kadrowania: twarz wypełnia niemal cały obraz. Intrygująco prezentuje się tu trajektoria spojrzenia: jego linia wprawdzie nie biegnie w kierunku odbiorcy, niemniej zostaje przeprowadzona niemal przez połowę zdjęcia, wyraźnie przy tym sugerując jej dalsze „przedłużenie” już poza kadrem. Tak ustawionego wzroku - mimo wszystko - nie można zignorować, zwłaszcza że intymne ujęcie umieszcza go w pozycji centralnej. Bliski kadr niejako sam z siebie narzuca odbiorcy koncentrację na oczach, nawet jeśli patrzą one gdzie indziej.

Ostatni przykład prezentuje „samotnego mężczyznę w nocy” (Wirpsza 1962: 28). I tym razem oba parametry uzyskują maksymalną, niczym niezakłóconą zgodność: odległa, wykadrowana w sposób bezosobowy postać spogląda w dół: nie nawiązuje z oglądającym żadnego kontaktu i pozostaje doskonale anonimowa.

Zasadniczym problemem pozostaje teraz kwestia wpływu, który powyższe właściwości wywierają na drugą część dyptyku. Można go, jak się wydaje, dostrzec na poziomie formalnym dotyczącym organizacji monologu. Podmiot przypomina tu zwiedzającego wystawę: określone cechy fotografii oddziałują na jego percepcję i w efekcie wywierają wpływ na niektóre parametry wypowiedzi lirycznej. W ten sposób w dyptykach Wirpszy funkcjonuje zasada analogii formalnej.

Ustawiona w pionie i zrównana z pozycją obserwatora fotografia sprawia, że wypowiedź liryczna może pozwolić sobie nie tylko na wspominaną redukcję deskrypcji, ale wręcz na swobodne - Wirpsza powiedziałby: ludyczne ${ }^{5}$ - przemieszczanie się po różnych fragmentach fotograficznej reprezentacji. Konsekwencją tej praktyki jest efekt ograniczonej figuratywności: podmiot prezentuje

5 Poeta przyznał w jednym z wywiadów, że Komentarze do fotografii są realizacją „elementu ludycznego" w jego twórczości (Szymański 1981: 164-165). 
jedynie pewien zakres danych wizualnych, a następnie przerywa ich dalszą ekspozycję, nie troszcząc się o uzyskanie kompletnego obrazu.

Analogia formalna pozostaje najbardziej wyrazista w zakresie kreowania postaci. Jeśli zatem - po pierwsze - fotografia posługuje się kadrem socjologizującym, usuwając lub neutralizując spojrzenie w obiektyw (por. Wirpsza 1962: 8, 12), wówczas w monologu lirycznym pojawią się prezentacje osób o wyraźnie stypizowanym statusie. Poetycki komentarz do zdjęcia rodzinnego (Koło pieca, Wirpsza 1962: 9) potwierdzi jedynie przynależność wszystkich postaci do grupy familijnej, nie dokonując przy tym właściwych dla tej społeczności rozróżnień. Zamiast matek, ojców, itp. poeta poprzestaje na podziale pokoleniowym (dzieci, dorośli, starcy, zmarli przodkowie), który jednak implicite odsyła do pełnionych w obrębie rodzinnej wspólnoty ról. Ten niski stopień typizacji znajduje swoje przeciwieństwo w monologu odnoszącym się do prawnika (Prawo, Wirpsza 1962: 13). Niemal wszystko, co zostaje stwierdzone na jego temat, ujmuje go jako reprezentanta tej profesji. Po drugie: fotografia operująca kadrem intymnym, eksponującym linię wzroku (por. Wirpsza 1962: 10), sprawia, że wypowiedź liryczna (Pragnienie, Wirpsza 1962: 11) dokonuje empatycznego zbliżenia, wydobywając z przedstawionej postaci to, co jednostkowe. Dotyczy to zarówno wyglądu zewnętrznego, jak też specyficznego, niestandardowego doświadczenia, które staje się udziałem sfotografowanego. Po trzecie wreszcie: tam, gdzie fotografia zakłada doskonale anonimową prezentację (por. Wirpsza 1962: 28), tam poetycki komentarz (Żałość, Wirpsza 1962: 29) poprzestanie na kreacji skrajnie schematycznej i uproszczonej, która pokazuje zachowanie „człowieka jako takiego” w obliczu utraty.

\subsection{Zasada transformacji znaczeń kompozycyjnych}

Interakcja z odbiorcą nie wyczerpuje sfery znaczeń, ponieważ sam obraz także zostaje wyposażony w tzw. wartość informacyjną, której nośnikiem jest jego kompozycja. Rodzaje i hierarchia sensów są zatem uzależnione od miejsca, jakie dany obiekt zajmuje w całościowej strukturze reprezentacji (Kress, Leeuwen 2006: 175-177). W fotografiach najczęściej realizowany jest typ kompozycji spolaryzowanej (dwuczłonowej) oraz ześrodkowanej. Zdjęcia wybrane przez Wirpszę do omawianych tu dyptyków należą - po dwa - do każdego z nich.

\subsubsection{Kompozycja binarna}

Kompozycja spolaryzowana jest charakterystyczna dla pionowego kadru. Polega ona na stworzeniu nacechowanej opozycji między tym, co znajduje się w górnej 
i dolnej części zdjęcia. W pierwszym przypadku obiektem reprezentacji jest to, co Idealne, w drugim - Realne:

Bycie Idealnym (Ideal) oznacza, że coś jest prezentowane jako wyidealizowana lub uogólniona istota informacji, dlatego też jest jej pozornie najważniejszą częścią. To, co Realne (Real), jest więc temu przeciwstawne, gdyż przedstawia bardziej konkretne [...] (np. detale), bardziej „przyziemne” [...] lub bardziej praktyczne informacje (Kress, Leeuwen 2006: 186-187).

Binarny układ może zostać złagodzony przez wprowadzenie trzeciego członu - tzw. Pośrednika (Mediator) - którego zadaniem jest łączenie czy mieszanie ze sobą obu przeciwstawnych aspektów.

Obie wybrane przez Wirpszę fotografie, których kadrowanie implikuje ogląd socjologiczny, są skomponowane wedle zasady „miękkiej” (tj. trójczłonowej) polaryzacji obejmującej bądź grupę (Wirpsza 1962: 8), bądź pojedynczą postać (Wirpsza 1962: 12). Pierwsze zdjęcie stanowi modelowy przykład dystrybucji znaczeń kompozycyjnych: znajdują się na nim trzy liczne, ustawione poziomo rzędy postaci, którym odpowiada podział na to, co idealne, pośrednie i realne. Pierwszy, umieszczony najwyżej, rząd składa się z fotografii „nieżyjącego najstarszego pokolenia" (Wirpsza 1962: 8): są to cztery obrazy dwóch małżeńskich par wykonane $\mathrm{w}$ dziewiętnastowiecznym stylu $\mathrm{z}$ charakterystycznym dla niego retuszem. Znaczenie idealne, abstrakcyjne oscyluje więc wokół sugestii, zgodnie z którą struktura rodzinna jest „zawsze już” obecna: trwa niejako poza czasem, łącząc kobiety i mężczyzn w kolejne związki, dzięki którym możliwe jest następstwo pokoleń. Znaczenie realne fotografii zostało zobrazowane w najniższym rzędzie osób, w którym znajdują się dzieci (troje), matka i babcia. Następstwo generacyjne zwraca uwagę na kwestię konkretnej opieki nad - już lub jeszcze najsłabszymi, przede wszystkim jednak stwarza rozmaite typy relacji, które wynikają z funkcjonującego w obrębie grupy pokrewieństwa. Środkowy rząd pośredniczy między górnym i dolnym: z jednej strony zawiera małżeńską parę i - prawdopodobnie - męża siedzącej niżej kobiety, a z drugiej: postacie te charakteryzują się wyraźnym podobieństwem rysów twarzy (chociaż dokładniejsze ustalenie więzi rodzinnych nie jest takie oczywiste).

Analogiczną kompozycją odznacza się fotografia „prawnika w todze” (Wirpsza 1962: 12). Trójczłonowy schemat został tu zbudowany na podstawie układu anatomicznego: najwyżej umieszczona została głowa (i twarz), najniżej - ręce oparte na książkach, a pośrodku, nieco w głębi znajduje się niewyraźny, częściowo zlewający się z tłem korpus siedzącego mężczyzny. Na jego spokojnej, 
zadumanej twarzy występują lekko uniesione brwi, oznaczające najprawdopodobniej ${ }^{6}$ zaskoczenie, ale także zaintrygowanie, może nawet ciekawość w reakcji na to, co zostało zakomunikowane przez drugą (niewidoczną na zdjęciu) osobę ${ }^{7}$. Fotografia sugeruje zatem, że istotą funkcjonowania prawa jest zdolność trafnego „przyswojenia” sytuacji nowych, niespotykanych wcześniej, które domagają się analizy i oceny w oparciu o istniejący stan prawny. W praktyce oznacza to wyszukanie odpowiedniego przepisu znajdującego zastosowanie do konkretnego przypadku: ten właśnie mechanizm unaoczniają ręce, które, wyposażone w długopis (lub pióro), kartkują rozmaite kodeksy. To, co zostało pokazane pomiędzy głową a rękami, sprowadza się do stroju. Dominuje tu bowiem prawnicza toga, która jednakże nie została szczelnie zapięta; przez „szparę” widać fragment koszuli i krawata. Zestawienie to podkreśla zarówno instytucjonalne umocowanie, jak i udział jednostki w rozstrzygnięciach wymiaru sprawiedliwości.

Jeśli przyjmie się ów rozkład znaczeń kompozycyjnych, można zauważyć, w jaki sposób liryczny monolog dokonuje jego modyfikacji. Utwór Koło pieca (Wirpsza 1962: 9) przeprowadza - niemal symultanicznie - dwie operacje: (1) reintegrację (i reinterpretację) tego, co pierwotnie idealne; oraz (2) odwrócenie opozycji między idealnym i realnym.

Pierwsza procedura jest efektowna, ponieważ Wirpsza ignoruje pionowy (i trójdzielny) układ kadru, „spłaszczając” go do jednego wspólnego pola: widok dzieci (najniższy rząd), dorosłych (środkowy) oraz portretów pradziadków (najwyższy) zostaje sprowadzony do tego samego znaczenia. Dodatkowo jeszcze mechanizm ten funkcjonuje wedle typowej dla kompozycji poziomej reguły datum - novum. Poeta zaczyna ogląd od lewego dolnego rogu zdjęcia: tu znajdują się nastoletnie dziewczynki, których mimikę w oczywisty sposób

6 Analizy mowy ciała niejednokrotnie kładą nacisk na dużą niejednoznaczność tego typu ekspresji: „Kiedy brwi unoszą się i uciekają ku zewnętrznej stronie, powodują spłaszczenie zmarszczek i tworzenie się serii horyzontalnych linii na czole. Taki stan określa się mianem marszczenia brwi i zwykle uznaje się go za oznakę zmartwienia. Może on jednak wskazywać dodatkowo na zdziwienie, zaskoczenie, radość oraz nieufność" (Webster 2014: 45). W kontekście działalności zawodowej zjawisko to interpretuje się m.in. w następujący sposób: „Zmarszczki poprzeczne powstają przy podnoszeniu brwi i zazwyczaj przy otwartych oczach. W ten sposób możliwe jest maksymalne otworzenie powiek, aby można było jak najwięcej postrzec, ponieważ dostępne informacje nie mogły zostać jeszcze zrozumiane lub przetworzone" (Rückle 2001: 170).

7 Opis odnoszący się do zachowań zawodowych wskazuje, że za pomocą uniesionych brwi m.in. „wyraża się również niewerbalne pytanie, zachęcenie do kontynuowania wypowiedzi”(Rückle 2001: 171). 
można skojarzyć $z$ udawaniem, z przyjętą na moment pozą. Jeśli tak zostanie zdefiniowane datum, wówczas kolejne dołożone przez podmiot liryczny „segmenty" (tj. novum) uzyskują analogiczny sens, który - przynajmniej prima facie - nie jest aż tak ewidentny jak datum. Na twarzach dorosłych dostrzeżony zostanie ten sam brak autentyzmu, a oblicza „najstarszego pokolenia” (Wirpsza 1962: 8) wprawdzie nie „uśmiechają się sztywno” (Wirpsza 1962: 9), ale zamiast tego pokazują - równie upozowane - dostojeństwo, namaszczenie, a nawet kategoryczność moralną. Konsekwentnie przeprowadzona reintegracja prowadzi do reinterpretacji: powstaje tu sens, który krąży wokół powszechnej nieautentyczności i fałszu właściwych dla obecnej i dawnej fotografii rodzinnej. Dzięki tej procedurze następuje zatem wymieszanie owych trzech poziomów, które w konsekwencji nadaje im nowy sens: to, co idealne, pośrednie i realne okazuje się w takim samym stopniu nierealne, tj. fikcyjne, wymyślone czy odegrane. I takie być musi, ponieważ będzie stanowić człon zbudowanej od nowa opozycji, której przeciwstawnym biegunem jest to, co prawdziwe, autentyczne.

Zgodnie $\mathrm{z}$ tą drugą procedurą poeta konstruuje przeciwieństwo, które charakteryzuje się niestandardowymi własnościami. Pierwszą z nich jest brak sfery mediacyjnej, pośredniej: obie części zostają zestawione na zasadzie silnego kontrastu, który wyklucza „płynne” przechodzenie między nimi. Druga cecha polega na wizualnej asymetrii: o ile bowiem w skład pierwszego członu przeciwieństwa wchodzi liczna grupa sfotografowanych, o tyle w skład drugiego - tylko jedna osoba. Jest nią najstarsza żyjąca kobieta (znajdująca się w najniższym rzędzie), o której podmiot liryczny wypowiada się aż dwukrotnie:

\section{Zwiotczałe mięśnie i skóra}

Starców nie jest już posłuszna woli (obłudnej) i wyobrażeniom

(Powstałym pod przymusem familijnego współżycia), tedy:

Przebija coś z prawdy, chyba z prawdy, bo skądże by ta uśmiechnięta

Drwina? Rozpad ciała służy prawdzie.

$[\ldots]$

Wnioskujemy więc, że na krótko przed śmiercią, wskutek

[nieposłuszeństwa ciała

Można powiedzieć prawdę: upozowaną koło pieca drwinę (Wirpsza 1962: 9).

W dość krótkim monologu lirycznym tak dokładne powtórzenie należy uznać za środek celowy. Polega on - i jest to trzecia z wymienianych cech - na rozdwojeniu czy zdublowaniu zasadniczej opozycji: widok siedzącej staruszki 
kontrastuje więc zarówno ze wszystkimi żyjącymi, jak i ze sportretowanymi przodkami. Jest to zabieg niezbędny, ponieważ w przypadku każdej z tych grup poeta wskazuje na zupełnie inny typ fizjonomicznej, by tak rzec, hipokryzji. Jeśli jednak opozycja mimo rozdwojenia nadal zachowuje silnie przeciwstawny charakter, oznacza to, że ów niezmienny człon odznacza się uniwersalnością. Osiągnięcie tego efektu wymaga jednak - cecha czwarta - prezentacji zdepersonalizowanej: o ile bowiem fotografia przedstawia jedyną (i dlatego niepowtarzalną) staruszkę, siedzącą w wygodnej pozycji na bujanym fotelu, o tyle monolog liryczny czyni z niej bezosobową alegorię starości jako takiej. W ten oto sposób poeta „podmienia” człony pierwotnej opozycji: to, co na zdjęciu było zaledwie częścią sensu konkretnego, w wierszu staje się wyłączną reprezentacją sensu uogólnionego. Schematycznie można to zilustrować następująco:

fotografia

PORTRETY

PRZODKÓW

strefa mediacji

strefa konkretu

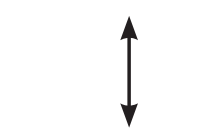

OSOBY DOROSEE

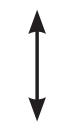

DZIECI, STARUSZKA, MATKA
Koło pieca

STARUSZKA

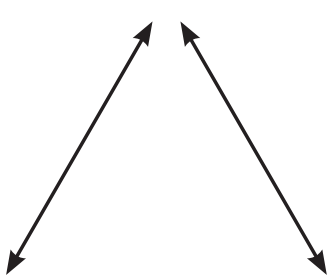

$\left[\right.$ Datum $_{1}+$ Novum $\left._{1}\right]+$ Novum $_{2}$

DZIECI, OSOBY

PORTRETY

DOROSŁE

Ten typ modyfikacji można określić jako uproszczenie kontrastowe, ponieważ jego celem jest przekształcenie tego, co ewoluuje stopniowo, wykorzystując subtelną grę podobieństw i różnic, w układ oparty wyłącznie na radykalnie ujętej (i odwróconej) różnicy. Zbudowanie mocnego kontrastu wymaga przede wszystkim usunięcia albo ujednoznacznienia strefy znaczeń mediacyjnych, tak aby można ją było scalić z wybranym członem opozycji. Drugi zabieg poety polega na dokonaniu kontrintuicyjnej substytucji: do ważniejszej sfery sensu abstrakcyjnego zostanie przeniesione to, co fotografia przedstawia jako konkretne, natomiast obszar „przyziemnych” znaczeń zostanie poszerzony 
o elementy wszystkich poziomów. Ta substytucja stwarza asymetrię ilościową, przede wszystkim jednak pokazuje, że wertykalne znaczenia kompozycyjne fotografii mogą być wymieniane czy podkładane, o ile będzie tu można wykorzystać horyzontalny system budowania sensu.

Typ modyfikacji zastosowany w utworze Prawo (Wirpsza 1962: 13) można nazwać uproszczeniem geometrycznym, w którym wizualna warstwa fotografii najpierw zostaje zredukowana do zestawu - ustawionych częściowo symetrycznie - linii, punktów (ewentualnie figur). W efekcie pierwotna reprezentacja znika niemal zupełnie, a w jej miejsce wiersz kreuje przedstawienie niefiguratywne przypominające malarską abstrakcję geometryczną. Mówiąc dokładniej, dochodzi tu do specyficznej fuzji obu porządków, ponieważ ów abstrakcyjny zestaw wykorzystuje zarówno kształty sfotografowanych obiektów, jak też - przede wszystkim - ich znaczenia. Ważne jest, że ta konstrukcja funkcjonuje niczym precyzyjny filtr, który do monologu lirycznego nie przepuszcza wykraczających poza nią danych wizualnych.

Proces geometryzacji został w utworze przeprowadzony dwukrotnie. Pierwsza próba polega na takiej prezentacji zdjęcia, która składać się będzie z trzech odwróconych trzech liter „V” w górnej części (są to linie widoczne na twarzy) oraz - odbitych symetrycznie, niczym w lustrze - także trzech „v” pojawiających się w dolnej części (są to linie dłoni oraz dwóch otwartych książek). Obie konstrukcje zostają w środku połączone kształtem zbliżonym do prostokąta, stworzonym przez odpowiednio ubrany korpus. Ten układ charakteryzuje się wyraźnie zaznaczoną linią wertykalną, nie zaskakuje zatem fakt, że dobierane do niego znaczenia respektują ten typ kompozycji. Najniżej w tej konfiguracji znajdują się dłonie spoczywające na dwóch kodeksach, co dla poety oznacza, że ta osoba reprezentuje jeden $\mathrm{z}$ trzech konkretnych zawodów istniejących w domenie sądowniczej (adwokata, sędziego, prokuratora). Dokładnie jednak nie wiadomo który, dlatego - przechodząc do środka - wystarczy przyjąć, że ubrany w togę mężczyzna jest po prostu prawnikiem. Linie układające się na twarzy oznaczają w tym pierwszym ujęciu troskę. Umiejscowienie kompozycyjne nadaje jej abstrakcyjny charakter, który dopiero w zestawieniu z pozostałymi elementami - tj. środkowymi i dolnymi - staje się bardziej konkretny, mający związek z funkcjonowaniem prawa w każdej z trzech jurystycznych sfer.

Jeśli podmiot liryczny unika przeprowadzenia precyzyjnych ustaleń, to zapewne dlatego, że dąży do odrzucenia tej pierwszej, samonarzucającej się wersji znaczeń. Druga prezentacja dąży do przeformułowania sensu abstrakcyjnego, dlatego pierwotny ogląd twarzy zostanie uzupełniony o nowe elementy: poziome „zmarszczki czoła” wraz z dwoma ustawionymi symetrycznie półłukami podniesionych brwi. Także w strefie środkowej pojawi się nowy, pionowy 
detal: toga bowiem nie zakrywa „wzorzystego krawatu”, który widoczny jest zwłaszcza pod szyją.

Dopiero dzięki tym dodatkom geometryczny schemat powstały na kanwie fotografii objawia prawdziwy, radykalnie inny sens. Zamiast „zatroskanego prawnika” monolog liryczny przedstawia „zmęczonego aktora”: linie czoła i brwi wyraźnie wskazują bowiem na udawanie (wystający spod togi krawat także), a w tym nowym kontekście symetryczny układ bruzd na twarzy oznacza tylko i wyłącznie przepracowanie czy znużenie odgrywaniem każdej z dostępnych prawnikowi ról. Takie odczytanie fotografii pokazuje, że zmiana sensu jest możliwa do przeprowadzenia w sposób bardziej niż poprzednio dyskretny: wertykalny układ znaczeń kompozycyjnych (i ich hierarchia) zostaje zachowany, modyfikacjom podlegają jedynie składniki najwyższego i najważniejszego poziomu. Sama operacja dodawania do niego kolejnych jednostek byłaby zaś niemożliwa, gdyby nie geometryczna zasada ich wyodrębniania i - zarazem pomijania innych. Budowanie abstrakcyjnych schematów jest tu efektywne, ale jednocześnie skrajnie arbitralne, gdyż nie uwzględnia wszystkich danych. Gdyby poeta wziął pod uwagę także „elipsy” oczu, wówczas może zwróciłby uwagę na trajektorię spojrzenia, która nie pozwala tak jednoznacznie odczytać gestu podniesionych brwi.

\subsubsection{Kompozycja centralna}

W przypadku układu ześrodkowanego zasada kompozycyjna wymaga pojawienia się dominującego obiektu w centrum, natomiast pozostałe fragmenty umieszczone zostają wokół niego (tj. na marginesie):

Bycie Centrum (Centre) oznacza, że coś jest prezentowane jako rdzeń informacji, któremu wszystkie inne elementy są w pewnym sensie podporządkowane. Marginesami (Margins) są właśnie te pomocnicze, podległe elementy. W wielu przypadkach Marginesy są identyczne lub przynajmniej bardzo do siebie podobne [...]. (Kress, Leeuwen 2006: 196).

Wybierając dokładnie przeciwstawne sposoby kadrowania - intymny i anonimowy - poeta zdecydował się na fotografie z centralnym układem znaczeń.

8 Warto zaznaczyć, że uproszczenie geometryczne realizowane jest bardzo konsekwentnie: przy dobrym powiększeniu tego zdjęcia widać wyraźnie, że wzory w krawacie są tworzone przez prostokąty pionowo ułożone w karo. 
W pierwszym przypadku (Wirpsza 1962: 10) zrobione zostało zbliżenie twarzy czarnoskórego mężczyzny, który pije wodę z zamocowanego nisko kranu. Żeby to uczynić, należało się schylić, a w celu odsłonięcia twarzy trzeba było przekrzywić głowę, dlatego na zdjęciu linia łącząca brodę i nos przebiega niemal dokładnie po przekątnej kadru (prawy dolny i lewy górny róg). Nie jest to pozycja łatwa do utrzymania, zatem wymaga odpowiedniego wsparcia. Taka jest, jak się wydaje, funkcja pozostałych części ciała, które dość fragmentarycznie (prawa ręka i dłoń, prawy bark, szyja) umieszczone zostały na marginesach fotografii. Tutaj także znalazło się samo urządzenie, tzn. kawałek kranu, które sprawia, że podjęty wysiłek jest celowy i uzasadniony. Jeśli zatem w centralnej pozycji znajduje się twarz z otwartymi ustami, do których wlewa się strumień wody, to owym rdzeniem informacji jest proces zaspokajania podstawowej potrzeby fizjologicznej, czyli pragnienia. Modelowy status tej kompozycji można dostrzec, analizując relacje centrum i marginesów: nasycenie wymaga zarówno środków (pozycja całego ciała), jak i właściwego dla siebie obiektu (woda z kranu). Zawartość tego, co najważniejsze (i wyśrodkowane), determinuje tu więc zakres owych uzupełnień, które pojawią się na obrzeżach.

Poetyckim komentarzem do tej fotografii jest utwór Pragnienie (Wirpsza 1962: 11). Charakter - tym razem podwójnych - modyfikacji znaczeniowych można tu określić mianem uproszczenia i uzupełnienia anatomicznego, ponieważ większość wprowadzonych przez poetę zmian dotyczy zaprezentowanego na zdjęciu ciała. Przebieg całej procedury jest trójstopniowy, chociaż pierwszy etap nie uzyskuje bezpośredniej tematyzacji, pozostając implicytnym warunkiem następnych. Jego istnienie można jednak stwierdzić, zestawiając obraz i monolog liryczny: ten ostatni nie zawiera bowiem żadnej wzmianki dotyczącej marginesów; jedynie to, co znajduje się w środku fotografii, przedostaje się do utworu. Izolacja sfery centrum dotyczy zresztą także anatomii, dlatego w wierszu nie pojawiają się informacje np. o wyciągniętej prawej ręce, o linii barków czy ułożeniu szyi. Ten sposób dezintegracyjnego patrzenia zostanie przeniesiony na drugi etap, w którym nastąpi „rozkład” samego centrum9. Poeta pominie tu - niezwykle wyraziście eksponowany na zdjęciu - owal twarzy; nic nie będzie wiadomo o brodzie, policzkach, czole, a przede wszystkim o brwiach. Zostaną tylko usta oraz oczy - i to, jakie znaczenia w nich mogą tkwić. Już

9 Ten właśnie mechanizm (chociaż bez poprzedzającego go warunku) dostrzegł Jankowicz, stwierdzając, iż w Pragnieniu ma miejsce „rozbici[e] przedstawionej na fotografii twarzy na nieprzystające do siebie części, obiekty częściowe [...]. Poeta pobudza wyobraźnię czytelnika, podsuwając mu obraz rozsypanych na fotograficznej kliszy fragmentów ciała" (Jankowicz 2017: 54). 
od samego początku ta dezintegracja osiągnie apogeum, ponieważ usta oraz oczy będą w pierwszej części monologu prezentowane oddzielnie, a przy tym asymetrycznie: pierwsze dokładnie i obszernie, drugie - lakonicznie. Tyle tylko, że za każdym razem jednostki sensu - np. przyjmowanie wody i ekspresja nieprzyjemnego uczucia - okażą się równie niewystarczające, niekompletne czy, być może, niespójne, antytetyczne. $Z$ tego zapewne powodu konieczne okazało się wprowadzenie etapu trzeciego, który odwrotnie niż poprzednie polega na uzupełnianiu, na wprowadzaniu dodatkowych danych. Ich status jest zaledwie hipotetyczny: składa się bowiem na nie to, czego sama reprezentacja nie zawiera, chociaż mogłaby. Intrygujący jest fakt, że owe dodatki zakładają inną płaszczyznę, inny - tzn. trzeci - wymiar, lokując się albo „przed”, albo „za” fotograficznym obrazem. Gdyby jednak dokonać tu swoistego rzutowania, które przeniosłoby elementy trzeciego wymiaru na pierwszy i drugi (tj. na płaszczyznę zdjęcia), wówczas okazałoby, że podmiot liryczny dokonuje tu restytucji tego, co wcześniej usunął, czyli marginesów (górnego i dolnego). Wydaje się zatem, że poeta, przekształcając obraz, nie jest w stanie zrezygnować z zasad kompozycji centralnej i to zapewne dlatego, że w tym typie relacja między środkiem a obrzeżami jest konieczna dla odczytania sensu.

Zastanawiają tu również aż dwie próby dodania nowych marginesów, przy czym pierwsza z nich ma charakter wyłącznie retoryczny. Nie tylko dlatego, że niemożliwe jest wiarygodne udzielenie odpowiedzi na pytanie: „co widzą te oczy / Ukosem w górę [...]?” (Wirpsza 1962: 11). Także dlatego, że konstruując zestaw hipotez, podmiot liryczny wyraźnie preferuje te, które przyniosłyby zagrożenie życia lub zdrowia. Naturalną, odruchową reakcją patrzącego byłby zatem strach, który jest manifestowany w czytelny sposób (układ oczu i brwi ${ }^{10}$ ). Jeśli zatem pierwsza próba zostanie odrzucona, to dlatego, że nie można jej uzgodnić ani z tym, co znajduje się na fotografii, ani z tym, co wcześniej zostało $\mathrm{z}$ niej do monologu lirycznego wyselekcjonowane ${ }^{11}$. Wiarygodna eksplikacja musi więc wzmocnić ów pierwiastek scalający: podmiot najpierw zintegruje

10 Można tu przytoczyć następującą definicję tzw. uniwersalnej ekspresji lęku: „Lęk uwidacznia się w wyglądzie brwi, czoła, oczu oraz ust. Te pierwsze unoszą się i zbiegają. Linie na czole stają się bardziej wyraźne, a na jego środku - częściowo marszczą. Powieki unoszą się, co sprawia, że bardziej widoczna staje się ta część białka, która leży nad tęczówką. Wargi rozciągają się na boki i układają na kształt poziomych linii” (Webster 2014: 40; por. też Andersen 2010: 65).

11 W tym przypadku rozpoznanie Kwiatkowskiego - zgodnie z którym poeta „stara się logicznie motywować swoje przypuszczenia; to, co jest poza obrazem, wywodzi z danych, jakie w obrazie są zawarte" (Kwiatkowski 1963: 9) - okazuje się zawodne. 
sensy odczytane (osobno) z oczu i ust, a następnie uzupełni tak powstałe centrum o równie anatomiczny margines, którego nie można już zakwestionować (pijący mężczyzna musi mieć żołądek). I ten właśnie „marginalny” element pozwala poecie wprowadzić do analizy obrazu czas: żołądek teraz „napełnia się bulgotem wody” (Wirpsza 1962: 11), ale już niedługo tejże wody w nim nie będzie. W tym właśnie sensie pragnienie fizjologiczne jest niezaspokajane i dlatego jego - zawsze tymczasowe - ugaszenie przynosi zamiast ulgi czy zadowolenia jedynie (dostrzeżony przez poetę w oczach) „grymas” i „męczarnię”.

W przypadku drugiej fotografii z kompozycją centralną prześledzenie zasad transformacji okazuje się niewykonalne, o czym zdecydował sam poeta. Umieszczając pod obrazem lakoniczny podpis - „Fotografia przedstawia samotnego mężczyznę w nocy na cmentarzu” (Wirpsza 1962: 28) - dopuścił się bowiem jawnej mistyfikacji ${ }^{12}$, w czym zapewne pomogła mu fatalna jakość zdjęcia opublikowanego w katalogu wystawy ${ }^{13}$, który stanowił podstawę dla poetyckiego tomu (por. Wirpsza 1962: 40).

Autorem tej fotografii jest Robert Frank, a jej oryginalny tytuł brzmi „Niedaleko Dworca Victorii” (Near Victoria Station) ${ }^{14}$. Przedrukowane w Komentarzach... zdjęcie zachowuje jedynie ogólną strukturę kompozycyjną: wykadrowany z dystansu mężczyzna ze spuszczoną głową pokazany zostaje na tle ciemnej, nocnej przestrzeni, w której znajduje się świecąca latarnia. Taki układ wraz ze sposobem kadrowania może wskazywać na samotność oraz anonimowość, ale nawet jeśli takie znaczenia faktycznie są tu obecne, to nie pozostają jedyne, a nawet - nie wydają się najważniejsze. Frank przedstawił bowiem biednego skrzypka - na wystawie fotografia znajdowała się w dziale pokazującym klęski materialne - stojącego na środku pustej londyńskiej ulicy. Tuż przed nim, na niewysokim murku znajduje się rozłożona chusta, a ani niej odwrócona czapka, do której przechodnie mogliby wkładać pieniądze. Mężczyzna jest w okularach i trzyma skrzypce opuszczone (w pionie), niemniej prawą ręką ewidentnie wykonuje ruch smyczkiem, a palcami lewej naciska na gryf. Za nim wyraźnie widać ulicę oraz - w tle - samochody, budynek (z drzwiami), trzy słupy latarń i dwa zapalone światła. Dramatyzm tej fotografii polega więc

12 W drugiej edycji Komentarzy Wirpszy zwrócił na to uwagę Grzegorz Jankowicz (Jankowicz 2017: 53), chociaż nie zaznaczył, że w pierwszym wydaniu mistyfikacja była niewykrywalna.

13 Zob. The family of man... 1955: 151. Tutaj zresztą pojawia się niezwykle lakoniczny podpis, informujący o nazwisku fotografa (Robert Frank) oraz miejscu wykonania (Anglia).

14 Dokładne reprodukcje można zobaczyć w zasobach internetowych (Frank 1951) oraz w drugim wydaniu tomu Wirpszy (Wirpsza 2017: 30). 
na samotności (w miejscu tak przecież uczęszczanym), z powodu której artysta chociaż by wykonywał wyrafinowane „sztuczki” (nietypowy sposób gry), to i tak nie zdobędzie żadnego wsparcia.

Dzięki niewyraźnej reprodukcji (oraz spreparowanemu podpisowi) Wirpsza w utworze Żałość (Wirpsza 1962: 29) dokonuje całkowitej wymiany scenografii. Proces przebiega w sposób niezauważalny i zamaskowany: czytelnik może być przekonany, że liryczny monolog wiernie przekazuje dane wizualne z fotografii. Kierując się ogólną strukturą kompozycji, poeta najpierw ustala znaczenie centrum: skoro smutny mężczyzna opiera się o krzyż, oznacza to, że stoi nad grobem kogoś bliskiego. Do tej wizyty musiała skłonić go typowa dla tego rodzaju czynności pora roku - jesień. W następnym ujęciu pojawia się eksplikacja (znacznie obszerniejszych niż centrum) marginesów: dookoła postaci rozciąga się zatopiony w mroku cmentarz, który zazwyczaj jest położony na przedmieściach. Nie zaskakuje zatem fakt, że w dalekim tle pojawiają się „sylwety kominów” (Wirpsza 1962: 29) widoczne dzięki światłu latarni. Trudno jest oprzeć się wrażeniu, że ów mocny punkt świetlny poeta „połączy” z analogicznym centralnym - tj. z twarzą mężczyzny - jedną linią (idącą niemal po przekątnej zdjęcia), która jednak nie kończy się na tymże obliczu. Jeśli bowiem ono także jest rozjaśnione, to źródło światła musi tu znajdować się nie za nim (w tle), ale - przed nim. Znowu Wirpsza sięga zatem po zabieg poetyckiego „dorabiania” marginesu: rozjaśnienie twarzy zostało dokonane przez (niewidocznego, znajdującego się z przodu) fotografa, który wykorzystał w tym celu reflektor, typowy dla techniki długiej ekspozycji.

Reasumując, poeta, bazując na kompozycji ześrodkowanej, wykonuje podobne jak w poprzednio omawianym utworze operacje, zmieniając zaledwie ich kolejność. Najpierw skupia się wokół centrum, które - i tu jest pewna różnica - tylko w niewielkim stopniu dekompletuje. Nie jest bowiem oczywiste, jak należałoby odczytać tylko ów jasny kwadrat chusty z okrągłym ciemnym otworem (widoczny nawet na zamieszczonej reprodukcji), dlatego monolog nawet o tym nie wspomni. To usunięcie gwarantuje przekonującą wykładnię środka obrazu przedstawiającego mężczyznę opartego o krzyż $\dot{z}^{15}$, która zostaje uzupełniona relacyjnie: najpierw o margines hipotetyczny (fotograf sterujący oświetleniem i kadrem), przedstawiany jednak jako wiarygodny, a następnie o margines faktyczny, obecny na „zdjęciu” (podmiejski cmentarz). Bazując na

15 Trzeba jednak zaznaczyć, że wyjaśnienie to jest przekonujące tylko do pewnego stopnia, pirma facie. Zamiast „krzyża” można na tej reprodukcji równie dobrze zobaczyć „miecz”, zwłaszcza że wspieranie się o krzyż na grobie nie należy do zachowań, by tak rzec, standardowych. 
tak odczytanym sensie kompozycji, monolog liryczny przejdzie do nieautentycznego (pokazowego) charakteru żałoby, której oddaje się sfotografowany anonimowy - człowiek.

Żałość wprowadza zatem uproszczenie i uzupełnienie scenograficzne. Różnica w stosunku do Pragnienia polega natomiast nie tylko na zamianie wymiaru manipulacji (scenografia zamiast anatomii), ale przede wszystkim na zastąpieniu pierwszego, przyjętego implicite etapu („odcięcie” marginesów fotografii) innym, bardziej radykalnym. Tutaj bowiem cała oryginalna fotografia została wyeliminowana, a na jej miejsce (w sposób równie utajniony i niepostrzeżony) wprowadzona została reprezentacja podobna i niepodobna zarazem; kopia, ale radykalnie oddalona od pierwowzoru, czyli coś, co Jean Baudrillard nazywał symulakrum. Strategię zaprezentowaną w tym dyptyku Wirpszy należałoby zatem określić jako symulację z uproszczeniem i rozszerzeniem scenograficznym.

\subsection{Zestawienie}

Na podstawie zanalizowanych powyżej realizacji przekładu intersemiotycznego można pokusić się o pewne uogólnienia. Zgodnie z pierwszym z nich już sama decyzja stworzenia foto-lirycznych dyptyków ma charakter znaczący. Wirpsza nie tylko sygnalizuje w ten sposób, że przekład obrazu na wiersz został tu dokonany, ale również sugeruje, że nie odbył się on bezwiednie czy przypadkowo. A jeśli tak, to posiada on własne prawa, które należy odkryć, mając do dyspozycji oba typy reprezentacji. Ten nieco oczywisty wniosek mógłby przybrać postać tezy, zgodnie z którą przekład intersemiotyczny składa się z zestawu poznawalnych operacji o różnym stopniu skomplikowania.

Przyglądając się dokładniej tym czterem przekładom, można zauważyć, że każdy z nich składa się z dwóch ogólnych (i niejednokrotnie ściśle ze sobą sprzężonych) procedur: negatywnej i pozytywnej. Pierwsza ma charakter dezintegrujący: jej zadaniem jest neutralizacja systemu przedstawień i znaczeń, który został zawarty w samym obrazie. Druga - przeciwnie - odznacza się dążeniem reintegracyjnym, które wykorzystując osiągnięcia poprzedniego etapu, zmierza do ustalenia innego oglądu i sensu. Przełożenie fotografii na język liryki jest więc dla Wirpszy równoznaczne z daleko idącą modyfikacją, której efekty mają być nie tylko niespodziewane, ale również odkrywcze, nieoczywiste.

Intrygujący jest fakt, że pierwsze dwie realizacje tej praktyki (por. 2.3.1), okazują się dość podobne. Najpierw dochodzi tu albo do redukcji jakościowej ( $z$ trzech sfer powstaje jedna), albo do redukcji ilościowej (usunięcie z każdej płaszczyzny tego, co wykracza poza filtr geometryczny). Następnie zaś dodany zostaje jakiś pominięty poprzednio element: na zasadzie albo substytucji 
(przesunięcie ze strefy trzeciej do pierwszej), albo suplementu (uzupełnienie o kolejne geometryczne detale). Jeśli więc za każdym razem oko poety pozostaje w obrębie samej fotografii, to można przypuszczać, że pozwalają mu na to jej właściwości. Zastosowanie podobnej praktyki aż dwukrotnie pozwala, jak się wydaje, przyjąć, że trójdzielna kompozycja pionowa połączona z uśrednionym kadrowaniem, właściwym dla perspektywy społecznej, stwarza w fotografii tak duży zakres znaczeń, że on sam może stanowić wyłączną podstawę procedur inkorporacyjnych. Sytuację taką określić można mianem przekładu wewnętrznego: jego celem jest zbudowanie wypowiedzi lirycznej, w której warstwa przedstawieniowa będzie zaczerpnięta wyłącznie $z$ fotografii, natomiast modyfikacje znaczeniowe, jakim obraz jest tu poddany, prowadzą do uzyskania sensu dokładnie przeciwstawnego, kontr-sensu.

W przypadku pozostałych realizacji (por. 2.3.2) podobieństwo nie jest już tak ścisłe, chyba że przyjmie się zasadę intensyfikacji jednego procesu. Faza dezintegracyjna polega tu bowiem na rozbiciu jedności kompozycyjnej fotografii (pozbawienie marginesów, atomizacja centrum) albo na „zamianie” zdjęcia, w wyniku której z pierwotnej kompozycji zostanie zaledwie enigmatyczny, nieczytelny ślad (nadal zresztą podatny na fragmentaryzację). Należy tu zauważyć, że operacje te są albo przemilczane, albo wręcz utajnione: za każdym razem monolog liryczny dąży do stworzenia iluzji, zgodnie z którą owe rozbite elementy w istocie wyczerpują wizualną (i znaczeniową) zawartość fotografii. Ten zabieg jest niezbędnym przygotowaniem fazy drugiej. Reintegracja polega tu bowiem na bezpośrednim i dobrze umotywowanym uzupełnianiu stworzonych wcześniej luk. Pojawiają się zatem nowe marginesy, których czysto poetycki charakter nie jest już ukrywany, ale, jak się okazuje, doskonale pasują one do tego, co już zostało o obrazie stwierdzone. Innymi słowy: reintegracja to taka substytucja marginesów, która utworzy spójną całość z wyizolowanym pierwotnym centrum. Dla przeprowadzenia tej procedury potrzebne są fotografie o ześrodkowanej kompozycji, które posługują się kadrowaniem albo bardzo bliskim, albo bardzo dalekim. Prezentacja zarówno intymna, jak i anonimowa ${ }^{16}$ unika bowiem oglądu w (usztywniającej) pespektywie socjologicznej - i zapewne dlatego jest niezwykle podatna na zewnętrzną ingerencję. Zrekapitulowaną strategię trzeba zatem określić jako przekład zewnętrzny: jego celem jest konstrukcja monologu lirycznego, który w warstwie przedstawieniowej będzie zawierał zarówno wybrane elementy fotografii, jak i dopasowane do nich uzupełnienia,

16 Trzeba tu jeszcze dopowiedzieć, że to właśnie dokonane przez Wirpszę usunięcie (przekształcenie) zdjęcia Franka niemal stwarza ów anonimowy kadr. Oryginał (Near Victoria Station) nie jest pod tym względem tak czysty i zawiera wyraźne elementy ujęcia socjologicznego. 
które są już oryginalnym konstruktem podmiotu. Funkcja tego, co przejęte, i tego, co dodane, wyznacza tu również kierunek zmian znaczeniowych: nowy obraz nie zawiera sensu opozycyjnego, ale przypomina zabieg precyzowania czy uściślania pierwotnych intuicji.

\section{Efekt(y) studium}

Obie fazy - negatywna i pozytywna - obecne w każdym typie przekładu wnoszą zasadniczy wkład w ostateczny sens tych monologów lirycznych. Pierwszym efektem przeprowadzonego przez poetę studium fotografii jest, jak wiadomo, „odrzucenie intencji fotografa” (Barthes 1996), a co za tym idzie - organizatorów wystawy The Family of Man. Jeśli ich zamiarem było pokazanie „zwierciadła uniwersalnych emocji w codzienności życia” (Steichen 1955: 5), zadanie to mogłoby zostać spełnione, o ile fotografie przedstawiałby człowieka bez maski, bez pozy, czyli bez zniekształceń wywołanych (aktualnym i przyszłym) oglądem innego. Tylko wówczas ludzkie postacie na zdjęciu mogłyby stać się wiarygodnym „nośnikiem” takich powszechnych sensów jak: zakorzenienie w rodzinnej ciągłości pokoleń, sumienna aplikacja prawa do konkretnych przypadków, trwałe zaspokojenie potrzeby fizjologicznej czy wewnętrzna potrzeba przeżywania żałoby. Jeśli poeta jest przekonany, że taki przekaz należy odrzucić, to dlatego, że jego prezentacja zakłada złą wiarę, której zewnętrznym wyrazem jest przyjęcie odpowiedniej postawy, wyrazu twarzy, gestu: to stworzenie innego ciała, uprzednie przekształcenie siebie samego w obraz (Barthes 1996: 19; por. Pietrzak 2014).

Aktorstwo, komedianctwo, udawanie, zmuszanie się, upozowanie - takie określenia wykorzystuje poeta, przeprowadzając demistyfikację. Co ciekawe, tę nieszczerą grę prowadzi nie tylko $\mathrm{z}$ innymi, w przestrzeni rodzinnej (Koło pieca) czy publicznej (Prawo), ale nawet z samym sobą, chociaż tu może ona mieć charakter bezwiedny (Pragnienie) lub zamierzony (Żałość).

Wirpsza zresztą nie poprzestaje na tej intuicyjnej konstatacji. W utworze Prawo pojawia się parenetyczne rozwinięcie owego komedianctwa:

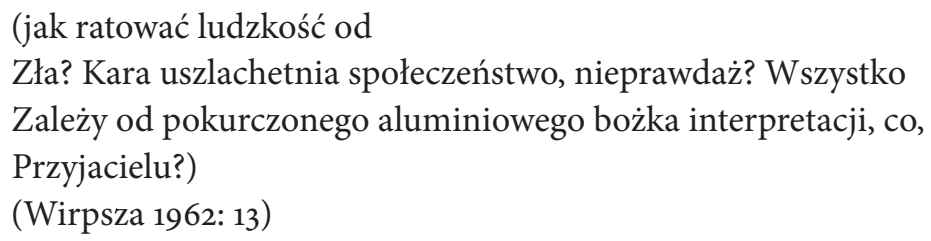

Te trzy pytania mogłyby należeć do wymienionych wcześniej przedstawicieli prawniczych profesji: sędziego, prokuratora i obrońcy (jemu najbardziej 
odpowiadałaby zamiana Temidy na Hermesa). Są trzy strony uczestniczące w procesie sądowym, a więc w sporze, którego stawka może być wysoka. Każda z tych instancji ma zasady i argumenty (zło, kara, względność) oraz środki perswazji (pytania retoryczne), ponieważ każda chce tego samego: przewagi, dominacji nad pozostałymi. Jeśli zatem przedstawiony na zdjęciu prawnik może być każdym z nich, to wiersz ten wyraźnie sugeruje, że przybieranie póz (komedianctwo) należy do zespołu somatycznych środków perswazji, które pojawiają się wszędzie tam, gdzie człowiek wkracza w międzyludzką (albo tylko wewnętrzną) interakcję. Wkracza zaś niemal zawsze i wszędzie, ponieważ... należy do rodziny człowieczej.

Gdyby zatem postawić pytanie: jaką rolę, według Wirpszy, pełni w tym procederze sama fotografia, to odpowiedź nie byłaby, jak sądzę, aż tak jednoznaczna. Oba utwory, w których zastosowano strategię przekładu wewnętrznego, zakładają działanie wewnętrznych napięć w obrębie samego obrazu. Dlatego nawet jeśli przedstawia on w sposób naturalny, spontaniczny coś, co w istocie jest pozą służącą propagowaniu odpowiedniej sprawy, to zarazem wciąż pozostaje on - by tak rzec - zbyt dokładny, zbyt prawdziwy. I dlatego zawiera również takie elementy - „rysy, pęknięcia, nieciągłości, zerwania, uskoki i zapadnie obecne na pojedynczych zdjęciach” (Jankowicz 2017: 53) - które, jeśli się je zauważy, znakomicie mogą podważyć ów spreparowany system. Tam natomiast, gdzie poeta zastosował strategię przekładu wewnętrznego, obecność tego, co subwersywne (Kałuża 2008: 157), jest niemal niedostrzegalna, dlatego trzeba dokonać zaplanowanych przesunięć i dopowiedzeń, aby to ostatecznie wydobyć.

Niezależnie od tego, czy poeta zaledwie odsłania czy współtworzy owo napięcie, nie ulega wątpliwości, że to właśnie dzięki temu może zaproponować własny, bardziej lub mniej odmienny od zwalczanego zestaw sensów. Tym, co najbardziej zaskakuje w pozytywnej wykładni, jaką zaproponował Wirpsza, jest jej równie kategoryczny, równie uniwersalny charakter. Własna wersja The Family of Man - mimo że oparta na tym, co autentyczne, a przy tym konkretne - także wymaga odpowiednich uogólnień. Poeta nigdy nie wprowadza ich bezpośrednio: wie, że na wystawie każdy dział (a niekiedy mniejsza grupa) zdjęć miał własne motto (literackie, filozoficzne, teologiczne, itp.) zaczerpnięte z tradycji całej ludzkości. Sam więc nie powtórzy tego gestu, każąc czytelnikom samodzielnie (i bez jednoznacznych gwarancji) domyślać się generalnych konkluzji, jakie można wyprowadzić z tych propozycji ${ }^{17}$. Gnomiczne zdanie:

17 Jak się wydaje, jest to podobna praktyka do tej, którą już międzywojniu zastosował Tadeusz Peiper, dyskretnie alegoryzując - i to $\mathrm{w}$ duchu religijnym - poetyckie utwory (zob. Jaworski 2003). 
„Rozpad ciała służy prawdzie” (Koło pieca; Wirpsza 1962: 9) wyraźnie krąży wokół Heideggerowskiego „bycia-ku-śmierci”, które paradoksalnie objawia się dzięki rodzinnej sukcesji pokoleń. Przedstawiona wyżej interpretacja Prawa daje się z kolei uzgodnić (na zasadzie metafory procesu sądowego) z Heraklitejską doktryną, głoszącą, iż „spór (polemos) jest ojcem powszechnym i królem” (Heraklit 2005: 22). Kolejna poetycka sentencja: „pragnienie jest niezaspakajalne” (Pragnienie; Wirpsza 1962: 11) jest już skrajnie wieloznaczna; biorąc pod uwage kontekst fizjologiczny, można tu wskazać chociażby na ewangeliczną rozmowę Jezusa z Samarytanką, w trakcie której pada stwierdzenie: „Każdy, kto pije tę wodę, znów będzie pragnął"18 (J 4,13). Gdy natomiast poeta stwierdza, że ktoś udaje żałobę, ponieważ „chce być [...] w porządku wobec siebie samego” (Żałość, Wirpsza 1962: 29), wówczas otwarte zostaje pole spekulacji psychologicznych, które, jak się wydaje, muszą zacząć się od słynnego pytania Freuda o trwanie żałoby po - faktycznie już odbytej - pracy żałoby (Żałoba i melancholia).

Takie konteksty można by mnożyć, spierając się o ich zasadność. Ważniejsza jest jednak funkcja, w ramach której te lub podobne znaczenia zostały przez Wirpszę zasygnalizowane. Poetycki komentarz do fotografii ma bowiem stworzyć drugą The Family of Man: inną, zdecydowanie bardziej pesymistyczną, ale równie przekonującą i autorytarną jak tamta pierwsza. Dopiero zestawienie tych dwóch propozycji - przypominające postawienie lustra (czy krzywego zwierciadła) przed fotografią - sprawia, że odbiorca doświadcza prawdziwie „dwubiegunowej” konfrontacji, którą z ukrycia reżyseruje poetyckie „ja”.

\section{| Bibliografia}

Andersen A. Peter (2010), Mowa ciała, przeł. Anna Zdziemborska, Dom Wydawniczy Rebis, Poznań.

Barthes Roland (1996), Światło obrazu. Uwagi o fotografi, przeł. Jacek Trznadel, Wydawnictwo KR, Warszawa.

Bernhart Walter (2007), Function of Description in Poetry, w: Description in Literature and Other Media, red. Werner Wolf, Walter Bernhart, Rodopi, Amsterdam-New York.

Frank Robert (1951), Near Victoria Station, https://tinyurl.com/rmym4398 [dostęp 26.09.2020].

Grądziel-Wójcik Joanna (2001), Poezja jako teoria poezji. Na przykładzie twórczości Witolda Wirpszy, Wydawnictwo Naukowe UAM, Poznań.

18 Cytat z Pisma św. pochodzi z Biblii Tysiąclecia (1980). 
Jankowicz Grzegorz (2017), Wirpsza i poetyka spojrzenia, w: tenże, Komentarze do fotografii, Instytut Mikołowski, Mikołów.

Heraklit z Efezu (2005), Zdania, przeł. Adam Czerniawski, słowo/obraz terytoria, Gdańsk.

Jaworski Stanisław (2003), Niespodzianki awangardy, w: tenże, Zakręty i przełomy. Studia o literaturze xx wieku, Collegium Collumbinum, Kraków, s. 23-34

Kałuża Anna (2008), Wola odróżnienia. O modernistycznej poezji Jarosława Marka Rymkiewicza, Julii Hartwig, Witolda Wirpszy i Krystyny Miłobędzkiej, Universitas, Kraków.

Kress Gunther, Leeuwen van Theo (2006), Reading Images: The Grammar of Visual Design, Routlege, London.

Kwiatkowski Jerzy (1963), Poezja infernalna, „Życie Literackie”, nr 16, s. 9.

Leśniak Kamila (2013), The Family of Man po latach. Wokół krytyki i recepcji wystawy, „Roczniki Humanistyczne”, nr 4, s. 205-240.

Pawelec Dariusz (2013), Wirpsza wielokrotnie, Instytut Mikołowski, Mikołów.

Pietrzak Wit (2014), Anty-mitologia Witolda Wirpszy. Komentarz do Komentarzy do fotografii, „Ruch Literacki”, z. 4-5, s. 505-515.

Rabb M. Jane (1995), Introduction. Notes toward a history of literature and photography, w: Literature and photography, interactions 1840-199o: a critical anthology, red. Jane M. Rabb, University of New Mexico Press, New Mexico, s. xxxv-lviii.

Rückle Horst (2001), Mowa ciała dla menadżerów, przeł. Tomasz Soróbka, Wydawnictwo Astrum, Wrocław.

Stala Marian (200o), Przeciw fotografii. O jednym wierszu Zbigniewa Herberta, w: Poznawanie Herberta 2, wybór i wstęp Andrzej Franaszek, Wydawnictwo Literackie, Kraków, s. 398-413.

Steichen Edward (1955), Introduction, w: The family of man; the photographic exhibition created by Edward Steichen for the Museum of Modern Art, Museum of Modern Art, New York, s. 4-5.

Szymański P. Wiesław (1981), Rozmowy z pisarzami, Znak, Kraków.

The family of man; the photographic exhibition created by Edward Steichen for the Museum of Modern Art (1955), Museum of Modern Art, New York.

Webster Richard (2014), Współczesna mowa ciała: kompletny przewodnik, jakiego potrzebujesz, przeł. Katarzyna Karczewska, Studio Astropsychologii, Białystok.

Wirpsza Witold (1962), Komentarze do fotografii, Wydawnictwo Literackie, Kraków.

Wirpsza Witold (2017), Komentarze do fotografii (2017), Instytut Mikołowski, Mikołów. 


\section{| Abstrakt}

\section{Cezary Zalewski}

W świetle powyższej (pobieżnej) analizy: Studium fotografii w Komentarzach do fotografii Witolda Wirpszy

Artykuł przedstawia sposób powiązania fotografii i poezji na przykładzie czterech utworów z Komentarzy do fotografii Witolda Wirpszy. Wyróżnione i zanalizowane zostały trzy obszary wzajemnych interakcji: (a) zasada funkcjonowania foto-tekstualnego dyptyku i rola, jaką pełni tu poetycki opis; (b) zasada analogii formalnej, zgodnie z którą niektóre parametry monologu lirycznego mają swoje źródło w formalnych właściwościach zdjęcia; oraz najważniejsza (c) zasada transformacji znaczeń kompozycyjnych. Polega ona na dwustopniowej interwencji: tekst poetycki najpierw stara się zneutralizować wizualne znaczenia kompozycyjne (faza negatywna), a następnie stwarza własną interpretację fotografii (faza pozytywna).

Słowa kluczowe: fotografia i poezja; Witold Wirpsza; The Family of Man

\section{| Abstract}

\section{Cezary Zalewski}

In the Light of the Above (cursory) Analysis: a Study of Photography in Witold Wirpsza's Comments to Photographs

The article presents the method of linking photography and poetry on the example of four poems from Witold Wirpsza's Komentarze do fotografii The Family of Man. Three areas of mutual interactions have been distinguished and analyzed: (a) the principle of functioning of the photo-textual diptych and the role of the poetic description; (b) the principle of formal analogy according to which some parameters of the lyrical monologue are derived from the formal proprieties of photos; and - the most important - (c) the principle of transformation of compositional meanings. It consists of the two-stage intervention: the poetic text first tries to neutralize the visual compositional meanings (negative phase), and then creates its own interpretation of the photography (positive phase).

Keywords: photography and poetry; Witold Wirpsza; The Family of Man 


\section{| Nota o autorze}

Cezary Zalewski - dr hab., teoretyk i antropolog literatury, historyk literatury II połowy XIX wieku; profesor nadzwyczajny w Katedrze Teorii Literatury Wydziału Polonistyki Uniwersytetu Jagiellońskiego. Autor wielu publikacji, w tym książek: Powracajaca fala. Mityczne konteksty wybranych powieści Bolesława Prusa i Elizy Orzeszkowej (2005); Pragnienie, poznanie, przemijanie. Fotograficzne reprezentacje $w$ literaturze polskiej (2010); Bolesław Prus jako estetyk. Sztuki piękne w dyskursie i praktyce prozatorskiej pisarza (2014); Źródło. René Girard i literatura (2015); Istnienie zdegradowane. Problem masochizmu w polskiej literaturze nowoczesnej (2017). E-mail: cezary.zalewski@uj.edu.pl ORCID: 0OOO-0001-6341-8592 